\title{
HERLING-GRUDZIŃSKI W DYSKUSJI Z NORWIDEM, KRASIŃSKIM I MICKIEWICZEM
}

\author{
Albert WALCZAK (Uniwersytet Warszawski) \\ ORCID: 0000-0003-0270-1591
}

W połowie lat 40. minionego stulecia Herling-Grudziński napisał kilka krótkich, ale istotnych esejów ${ }^{1}$ dotyczących literatury i myśli polskiego romantyzmu. Dialog z epoką Mickiewicza, przynajmniej w takim natężeniu, nie powróci już do rozważań Herlinga; nazwiska polskich wieszczów, chociaż będą pojawiać się również w następnych latach, to raczej na marginesie twórczości, przy okazji innych wątków, często jedynie dla podkreślenia erudycji polskiego literata. Rzeczą znamienną pozostaje zatem, że w momencie kształtowania się powojennej polityki Europy, tragicznej w skutkach dla Polski, późniejszy diarysta poświęci dość dużo miejsca romantyzmowi. Herling podąża śladem poprzednich pokoleń, które w związku z istotnymi wydarzeniami w historii narodu (powstanie styczniowe czy odzyskanie niepodległości) uznawały, że należy ustosunkować się do paradygmatu romantycznego. Komentując polemikę, jaką podejmuje Herling z przeszłością, także z romantyzmem, Arkadiusz Bagłajewski stwierdza: „Herling, po doświadczeniach łagrowych, pisze wszak o wartościach, o dziedzictwie

\footnotetext{
${ }^{1} \mathrm{~W}$ tym miejscu należy przypomnieć rozważania Anity Moniki Frankowiak o gatunku, jakim jest esej, w kontekście refleksji o twórczości Herlinga. Badaczka zauważa, że „Esej (szkic) [autorka używa tych pojęć zamiennie - A. W.] jest gatunkiem, który wymyka się jednoznacznym rozstrzygnięciom terminologicznym”. Frankowiak zestawia ze sobą szereg definicji i chociaż zaznacza, które omówienie jest jej zdaniem najbliższe eseistyce Herlinga, nie zapomina, że ujęcie to nadal budzi wiele wątpliwości. Por. A. M. Frankowiak, Być wśród żywych i umarlych. Ewolucja twórczości eseistycznej Gustawa Herlinga-Grudzińskiego, Olsztyn 2003, s. 9-12. W podobnym tonie wyraża się Andrzej Waśko: „Przez eseistykę rozumiemy tu więc nie tyle określony gatunek, ile szeroko pojęte pisarstwo form pośrednich”. A. Waśko, Prawda i parabola. O Gustawie Herlingu-Grudzińskim, [w:] Herling-Grudziński i krytycy. Antologia tekstów, wybór i oprac. Z. Kudelski, Lublin 1997, s. 100-101. Z tego też względu my również decydujemy się na zamienne używanie określeń „esej” i „szkic”.
} 
wciąż aktualnym, które jednakowoż trzeba poddać reinterpretacji”’2. Frankowiak ponadto zauważa, że pisarz jest „,bliski tradycji romantycznej i z niej czerpie siłę do walki o moralne i fizyczne wyzwolenie człowieka”, ${ }^{\text {. }} \mathrm{Z}$ wypowiedzi literaturoznawców wynika, że podejście emigranta do dziedzictwa romantycznego nie jest jednoznaczne, jawi się on jako tropiciel idei, co tym bardziej skłania do podjęcia refleksji nad wybranymi esejami. Grudziński jest świadom, że czasy mu współczesne, abstrahując od słuszności takiego myślenia, będą niewątpliwie budzić wśród rodaków skojarzenia z sytuacją, która nastała tuż po klęsce powstania listopadowego — stąd też „żywi” muszą odnieść się do „umarłych”; szukać w myśli przodków nie tylko cennych wskazówek, lecz także (a może nawet $\mathrm{w}$ pierwszej kolejności) poddać ją należytej ocenie $\mathrm{w}$ związku z nowymi wyzwaniami, jakie stoją przed Polakami zarówno w kraju, jak i na emigracji.

Zanim przystąpimy do analizy esejów, dodajmy, że w rozważaniach pomijamy tak ważne dla Herlinga teksty o romantyzmie, jak Nota o Brzozowskim czy Wyzwolenie od romantyzmu?. Chociaż są to szkice nawiązujące do interesującej nas epoki, to Herling dyskutuje w nich w pierwszej kolejności z autorami tworzącymi później, działającymi na przełomie XIX i XX stulecia: Brzozowskim i Wyspiańskim. Chcemy natomiast przyjrzeć się polemice z samymi twórcami (Mickiewicz, Krasiński, Norwid) czy, ściślej, ich tekstami bezpośrednio związanymi z epoką romantyczną. Zastrzeżenia do przyjętego klucza można mieć $\mathrm{w}$ odniesieniu do ostatniego $\mathrm{z}$ wymienionych poetów. Żywe do dzisiaj dyskusje, czy Norwida powinno w ogóle zaliczać się do pokolenia romantyków, czy też widzieć w nim premodernistę, są bez wątpienia zasadne. Sam Herling także dostrzega odmienność autora Vade-mecum i stawia go na innym planie — w jednym ze szkiców wspomina o „Trójcy Romantycznej i Norwidzie” [Przezwyciężanie żeromszczyzny, s. 56] $]^{5}$. Niezależnie od tego typu sporów lektura eseju poświęconego Norwidowi nie stanowi przeszkody, a wręcz pomaga w lepszym zrozumieniu stosunku uczestnika bitwy pod Monte Cassino do Mickiewicza czy Krasińskiego. Jak zaznacza Jerzy Święch: „Norwid [...] dla Herlinga był sojusznikiem w walce przeciw nałogom romantycznego myślenia, anachronicznego w sytuacji, gdy Polska upokorzona i zdradzona przez sojuszników, musi nie cierpiętnictwo, lecz hart ducha wykrzesać z siebie" $"$.

\section{Herling-Grudziński a Norwid}

Zaczniemy od analizy konfrontacji autora Dziennika z Norwidem. Podejście to jest uzasadnione nie tylko podobną postawą Herlinga i Norwida wobec romantyzmu, lecz także względami chronologicznymi. Interesujący nas tekst jest najwcześniejszy ze wszystkich omawianych: ukazał się w 1945, a powstał w październiku 1944 roku. List C.K. Norwida do emigracji polskiej otwiera debiut książkowy Herlinga, co symbolicznie wskazuje, że analizując jego myśl, warto mieć w pamięci autora Czarnych kwiatów

\footnotetext{
${ }^{2}$ A. Bagłajewski, ,Żywi i umarli” — czytani po latach, [w:] Herling-Grudziński i krytycy, s. 398.

${ }^{3}$ A. M. Frankowiak, Być wśród żywych i umarlych, s. 22.

${ }^{4}$ Por. rozważania Bagłajewskiego dotyczące możliwości odczytania tytułu debiutanckiej książki Herlinga Żywi i umarli - A. Bagłajewski, „Żywi i umarli” — czytani po latach, s. 400.

${ }^{5}$ Por. G. Herling-Grudziński, Przezwyciężanie żeromszczyzny (O „, Miliardach” Andrzeja Struga), [w:] tegoż, Recenzje, szkice, rozprawy literackie. 1935-1946, zebrał. Z. Kudelski, oprac. W. Bolecki i in., t. 1, Kraków 2009, s. 56. Wszystkie cytowane fragmenty esejów Grudzińskiego pochodzą $\mathrm{z}$ tego wydania (chyba że zaznaczono inaczej), a numery stron są podawane w tekście głównym w nawiasach kwadratowych.

6 J. Święch, Literatura polska w latach II wojny światowej, Warszawa 2010, s. 466.
} 
(ku podobnej tezie skłania się Bagłajewski ${ }^{7}$ ). Aby lepiej zrozumieć znaczenie Norwida dla myśli Herlinga, należy odnieść się do nieco późniejszego tekstu pisarza, Mowy cieni, w którym Herling mówi wprost o wadze poety:

Piękno jego sztuki leży w sile niezmożonej rzeczy, skądciś wiodących swój ród i dokądś zmierzających w swej głębokiej, choć często nie ujawnionej potrzebie istnienia i działania. [...] Norwid dobudowuje sklepienia kamiennym ścianom na chwilę przed ich ostatecznym skruszeniem. Ten obraz ruin z wczoraj, posyłających swe ostatnie pozdrowienie i sekret piękna tworom jutra, jest artystycznym wyznaniem wiary autora Promethidiona. [...] Norwid jest poetą zw ycięskiej tradycji. [Mowa cie$n i$, s. 289]

W tym fragmencie z łatwością można dostrzec, dlaczego poglądy Norwida wydają się Herlingowi tak atrakcyjne. Po pierwsze poeta, dla którego wielkim autorytetem był August Cieszkowski, afirmuje postawę aktywną, twórczą, krytykując zarazem próżność. Po drugie ,poeta ruin” występuje jako strażnik ważnej dla Herlinga tradycji kultury europejskiej. Kiedy Norwid, powtórzmy, „dobudowuje sklepienia kamiennym ścianom” i jednocześnie zwraca uwagę na „ostatnie pozdrowienie” dawnej kultury, staje się przewodnikiem po dziedzictwie przodków. Takie postępowanie nie jest obce Herlingowi, który niebawem, czy to na łamach Dziennika, czy innych pism, zacznie komentować wielkie dzieła sztuki. W tym samym szkicu autor wspomina o wierze poety w ,ponadczasową trwałość dzieł ludzkich” [s. 289], z czym spotykamy się również w pismach dwudziestowiecznego emigranta. Wreszcie, i chyba najważniejsze (na co wskazywałoby podkreślenie autora eseju): Norwid jest ,poetą zwycięskiej tradycji”. Herling potwierdza zatem swoją aprobatę dla racji głoszonych niegdyś przez Norwida. Dialog z twórcą Vade-mecum odbywa się na innej zasadzie niż z Krasińskim czy z Mickiewiczem. Otwierający $\dot{Z} y w y c h i$ umartych esej, który rozpoczyna się od przytoczenia w całości listu Norwida, to w zasadzie próba przekazania nowej emigracji myśli poety bez wprowadzania niezbędnych poprawek. O ile z dwoma wieszczami Herling wejdzie w polemiczny dialog (aczkolwiek przebiegający w życzliwej atmosferze), o tyle w eseju umieszczonym w Żywych $i$ umartych będzie po prostu podążał za Norwidem.

Pośrednio wskazał na to chociażby przywoływany wcześniej Bagłajewski, pisząc, że „List Norwida powinien nazywać się »Listem Herlinga do Emigracji Polskiej«, następujący po nim komentarz to $\mathrm{w}$ istocie rozpisanie Norwidowskich tez $\mathrm{z}$ akcentem na współczesność" ${ }^{\prime 8}$. Interesujące, że Herling do przedstawienia swoich spostrzeżeń wykorzystuje prywatny list Norwida do Józefa Ignacego Kraszewskiego pisany w maju 1866 roku, nie zaś podejmujące już wcześniej ten problem Listy o emigracji, które ukazały się na łamach „Dziennika Polskiego” w 1849 roku'. W ten sposób, tzn. tytułując swój esej jako List C.K. Norwida do emigracji polskiej, Herling niejako włącza odłam korespondencji z Kraszewskim do cyklu listów pisanych z myślą o publikacji na łamach gazety redagowanej przez Karola Libelta. Dopiero w późniejszej części szkicu autor informuje o prawdziwym adresacie epistolografii Norwida, co jednak nie zmienia faktu, że list poety należy czytać jako wezwanie do wszystkich emigrantów.

\footnotetext{
${ }^{7}$ Por. A. Bagłajewski, „Żywi i umarli”-czytani po latach, s. 400.

${ }^{8}$ Tamże.

${ }^{9}$ Co ciekawe Zofia Stefanowska, analizując stosunek Herlinga do emigracji przedstawiony na kartach Dziennika pisanego noca, zwraca uwagę na zgodność myśli diarysty z tezami Norwida wyrażonymi właśnie w Listach o emigracji. Badaczka nie odnosi się jednak do eseju z Żywych i umartych. Por. Z. Stefanowska, „Dziennik” Herlinga-Grudzińskiego, [w:] Herling-Grudziński i krytycy, s. 331.
} 
Wypowiedź Norwida autor Innego świata określa jako ,glejt żelazny, wystawiony w tych ciężkich dniach burzy polskiej na dalszą trudną i niepewną drogę” [s. 486]. Esej pisany w obliczu klęski powstania warszawskiego, a wspierany myślą Norwida, ma pełnić funkcję przestrogi, specyficznej instrukcji, nie tylko dla emigrantów, ale dla całej Polski. Myśl poety jest nadal aktualna, zwłaszcza że list ten został napisany „W równie dla Polski chmurnych czasach” [s. 486]. Herling nie spiera się z żadnym ze sformułowań przekazanych w liście do Kraszewskiego; widzi w twórcy Czarnych kwiatów mistrza potrzebnego nowej emigracji, o czym daje znać m.in. poprzez szereg zestawień dotyczących Norwida: „Nie wieszcz, ale mędrzec, nie prorok, ale gorzki ostrowidz, nie wróż, ale mistrz" [s. 486]. Zauważmy, że wszystkie użyte określenia to dobitnie wyrażona opozycja (oczywiście zarysowana w dopuszczalnym $w$ tego typu tekście uproszczeniu) między myśleniem romantycznym a antyromantycznym. Mędrzec jest przecież kimś, kto ma prawo napominać $\mathrm{z}$ racji posiadanej wiedzy i zdobytego doświadczenia; nie jest trudnym do zdefiniowania „wieszczem” czy, co brzmi bardzo pejoratywnie, „wróżem”, który z jakichś nieokreślonych powodów rości sobie prawo do głoszenia ogólnych prawd.

Herling odnajduje w Norwidzie tak jego zdaniem potrzebnego Polsce rewizjonistę (,gorzki ostrowidz”) myślenia wallenrodycznego, „który z poezji uczynił lancet, odsłaniający najdrobniejsze włókna duszy narodu” [s. 486]. Poeta, nazwany w eseju „królewskim nędzarzem”, zostaje przedstawiony przez Herlinga jako swoiste „sumienie narodu" wypowiadające trudne, acz niezbędne prawdy o rodakach. Ponadto Herling przez charakterystykę postawy Norwida wskazuje równocześnie na powinności współczesnego pisarza. Celowo posłużyliśmy się tu słynnym określeniem odnoszącym się do Żeromskiego. W końcu Norwid, podobnie jak Żeromski, ,sięgał do dna polskich nieszczęść" [s. 486], a taka postawa jest szczególnie ważna dla Herlinga. Na pytanie Włodzimierza Boleckiego, czy bliskie jest mu stwierdzenie Żeromskiego, że do obowiązków pisarza należy „rozdrapywanie ran, aby nie zarosły błoną podłości”, twórca odpowiada: „Nie tylko jest mi bliskie, ale je uwielbiam i bardzo często je stosuję"10. Potwierdza to Zdzisław Kudelski: „Herling jako emigrant polityczny z wyboru, wielokrotnie wykorzystuje prawo do mówienia prawdy, choćby była trudna, wbrew społecz-

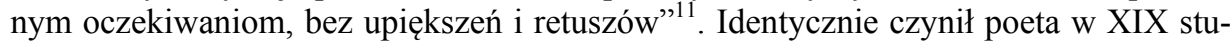
leciu. Norwid pisze swój list, jak już przypomniał Herling, w znamiennym czasie, po powstaniu styczniowym, czyli w perspektywie możliwych kolejnych emigracji, kiedy też autor Vade-mecum ma przed oczyma nieprzychylnie przez niego ocenianą Wielką Emigrację $^{12}$. W korespondencji (którą w przypadku Norwida Herling traktuje na równi z dziełem artystycznym ${ }^{13}$ ) z Kraszewskim ,gorzkie prawdy” zostają wypowiedziane bez retuszu. Taka retoryka zyskuje uznanie Herlinga, który zaznacza, że „los własnego narodu można zdradzić lub dzielić, ale nigdy, przenigdy nie wolno go skłamać" [s. 486]. Nic więc dziwnego, że późniejszy diarysta decyduje się zapytać: „Czy to nie On właśnie powinien być dla nas symbolem niezatartym narodu, który tułaczkę i poniewierkę prze[d]kłada nad niewolę?" [s. 486].

\footnotetext{
${ }^{10}$ G. Herling-Grudziński, W. Bolecki, Rozmowy w Dragonei, Warszawa 1997, s. 322.

${ }^{11}$ Z. Kudelski, Studia o Herlingu-Grudzińskim. Twórczość - recepcja - biografia, Lublin 1998, s. 36.

${ }^{12}$ Por. np. W. Rzońca, Norwid a romantyzm polski, Warszawa 2005, s. 178.

13 „Jeżeli wypadnie nam kiedyś zrekonstruować ostatecznie twórczość Norwida, listy będą w niej sąsiadowały na równych prawach z najpiękniejszymi utworami sztuki poetyckiej” [Listy literackie, s. 316].
} 
Oczywiście symbol ten pod żadnym pozorem nie jest przyjmowany przez emigrację, zarówno tę dziewiętnastowieczną, jak i późniejszą. Norwid w swoim liście kilkakrotnie korzysta ze sformułowania „Nie mogę mówié”, niemniej jednak na przekór tym boleśnie brzmiącym słowom wypowiada swoje surowe oceny dotyczące Polaków. Ten zarzut jest również ważny dla Herlinga, który w późniejszej części eseju przytacza po raz kolejny, teraz już wyselekcjonowane, fragmenty listu Norwida, aby krótko je skomentować, potwierdzić ich aktualność. Do słów poety „niemocni słowa świadectwa” eseista dodaje: „wszyscy ci mali »organicznicy« i pozytywiści [...] mniejsi od swych mistrzów" [s. 487]. Rozgrywa się tym samym Norwidowsko-Herlingowska walka z tymi, którzy nie są gotowi zaufać „następstwom prawdy” [s. 485]. Norwid „uzasadnia”, dlaczego jego sądy nie mogą zostać wypowiedziane: „Tego wszystkiego mówić nie mogę dlatego, dlatego że poprzednicy moi byli ludzie genialni, ale łgarze, tak jak każdy patrycjusz w trudnych chwilach rzeczypospolitej jest łgarzem" [s. 485]. Herling w październiku 1944 roku obawia się, że wobec kolejnych klęsk narodu powstaną nowe, tak przez niego negatywnie oceniane mity, fałszywie thumaczące porażki. Obawia się tego, ponieważ zdaje sobie sprawę, że te mylne interpretacje zostaną mimo wszystko przyjęte, gdyż wypowiedzą je „ludzie genialni”, choć „łgarze”. Realna ocena sytuacji zaniknie w morzu anegdot, na co zwraca uwagę także Norwid: „Bądź im Pindarem albo Buonarrotim... na co?... Im trzeba, abyś był bankierem-Żydem i abyś gadał anegdoty jak Radziwiłł Karol” [s. 485]. Pisarzowi natomiast zależy na opisaniu rzeczywistości prawdziwej, nie zaś zmitologizowanej, ponadto spostrzega, że „Rwie się smutny polski wątek, gubi się myśl bezinteresowna wśród »wieści i zachodów wojennych«" [s. 487]. Chłodne spojrzenie zanika wobec gwałtownej możliwości nieprzemyślanej próby rozwiązania trudnej sytuacji, co również dla Norwida jest nie do przyjęcia: „Oto gotowi wylać morze krwi, ale kilku wyrazów prawdy nie powiedzą" [s. 486].

W zamian za to Norwid i Herling proponują postawę zdecydowanie aktywną, na swój sposób stanowiącą echo romantycznej filozofii czynu, czynu jednakże rozumianego przez pokorną pracę, która decyduje zarazem o odrzuceniu myślenia w kategoriach mesjanistycznych. „Kiedy kto Demokrata, niech będzie szlachetnie dumny jak Cato i pracowity, i cichy" [s. 486] — zastrzega Norwid. Zestawienie tych dwóch cech (,pracowity i cichy”) prowadzi do zaakceptowania pokory jako najwłaściwszej postawy. W dodatku arystokracja, którą poeta określa jako „bez grzeczności i starannej baczności uszanowania człowieka” [s. 485], od teraz musi stać się „delikatnym i artystycznie niebieskim jak Perykles" [s. 486]. Te propozycje, bez protestów zaakceptowane przez Herlinga, składają się na nową, czy jak chce Frankowiak, „nowoczesną koncepcję narodu"14, która oznacza zarazem próbę ,rewizji stereotypu emigracyjnego"15.

Herling, zmierzając do konkluzji swoich rozważań wspomaganych dialogiem z Norwidem, podkreśla: „Jeśli Polacy są naprawdę narodem romantycznym to jest to anachronizm [...] Jeśli są naprawdę narodem niepodległym, to jest to prawda" [s. 487]. Autor Żywych i umarlych dokonuje zatem rozgraniczenia pojęciowego między „narodem romantycznym” a „narodem niepodległym”. Ten pierwszy naród jest skazany na porażkę, ponieważ „cierniem tkwi w żywym ciele Europy” [s. 487]. Następuje zatem zanegowanie wartości romantycznego mesjanizmu ${ }^{16}$ na rzecz narodu działającego, który „układanej do snu śmiertelnego Europie każe zawsze przecknąć się do życia na nowo" [s. 487]. Niemniej trzeba zaznaczyć, że Herling w pewnym momencie sam

\footnotetext{
${ }^{14}$ A. M. Frankowiak, Być wśród żywych i umartych, s. 27.

${ }^{15}$ A. Bagłajewski, ,Żywi i umarli”-czytani po latach, s. 400.

${ }^{16}$ Por. A. M. Frankowiak, Być wśród żywych i umarlych, s. 27.
} 
kontynuuje myśl romantyczną obecną w niektórych wizjach mesjanizmu. Definiuje Polskę jako naród, który czuwa, aby Europa „nie zasnęła”; w ten sposób pisarz niejako zapowiada silny opór Polski wobec rodzącej się hegemonii Związku Sowieckiego. Idąc tym tropem, można powiedzieć, że ten, który zna historię Polski, wie doskonale (ale w żadnym razie nie „wieszczy”!), że Polska, jak niegdyś po rozbiorach, tak i teraz po 1945 roku, będzie przeciwstawiać się zagrożeniu ze Wschodu. Herling pokazuje, że „niepodległość” w jego pojmowaniu oznacza nawet nie tyle granice wyznaczone na mapie, co po prostu wolność myśli czy sprzeciw wobec zastanej sytuacji (nie bez przyczyny naród niepodległy w dociekaniach eseisty jest, jak cytowaliśmy, synonimem „prawdy”).

List C.K. Norwida do emigracji, który otwiera dialog Herlinga z romantyzmem, pokazuje, $\mathrm{z}$ jakiej perspektywy dwudziestowieczny pisarz spogląda na tę ważną w dziejach Polski epokę. Herling neguje za poetą niektóre wizje romantycznego spojrzenia na naród czy emigrację. Słowa, które Wiesław Rzońca odnosi do Norwida, tj. „krytyka łatwego (krzepiącego serce) patriotyzmu, którego rewersem jest narodowe (emigracyjne) oszołomienie" "17 , równie dobrze można odnieść do Herlinga-Grudzińskiego. Należy przy tym jednak pamiętać, że autor Innego świata dostrzega także walory charakteryzowanej epoki, co wyniknie przy okazji analizy szkiców poświęconych Krasińskiemu i Mickiewiczowi (a nawet w powyżej przedstawionym eseju wobec romantyków pada określenie „mistrzowie”). Zamykając rozważania o Herlingu w rozmowie z Norwidem, wspomnijmy, że twórcę Vade-mecum można z pewnością postawić obok takich Herlingowskich wzorców, jak Conrad i Dostojewski ${ }^{18}$. Nie bez przyczyny w słowniku Herlinga znajduje się miejsce dla „surowej, po norwidowsku pięknej moralności” [Wspomnienie o K. L. Konińskim, s. 496].

\section{Herling-Grudziński a Krasiński}

Krótki esej Herlinga-Grudzińskiego Nad „Nie-Boska komediq” zamieszczony w 1946 roku na łamach emigracyjnego tygodnika „Orzeł Biały” nosi podtytuł Propozycja dyskusyjna. Istotnie bowiem prezentowana lektura najgłośniejszego dramatu Krasińskiego w wielu miejscach wymyka się tradycyjnym, czy raczej najbardziej popularnym, odczytaniom utworu. Innego zdania jest Tatiana Olejnik, która napisała, że „Esej Grudzińskiego zamierzonej dyskusji wywołać nie mógł, ponieważ jego poglądy są zadziwiająco zbieżne z innymi wypowiedziami na temat Nie-Boskiej i ukazanej w niej koncepcji rewolucji” ${ }^{\prime 19}$. Z pewnością w stwierdzeniu tym jest dużo racji. Wystarczy porównać niektóre spostrzeżenia Herlinga z klasycznymi uwagami chociażby Juliusza Kleinera o dramacie, do których przyjdzie nam się odwołać ${ }^{20}$. Wydaje się jednak, że pewne sugestie emigranta są niepowtarzalne; autor szkicu jest krytyczny wobec ówczesnych interpretacji dzieł Krasińskiego. Dla eseisty przecież w połowie lat 40. minionego stulecia $\mathrm{w}$ treści dziewiętnastowiecznych dzieł liczy się przede wszystkim ich aktualna wymowa, możność odniesienia dawnych treści do bieżących kwestii polityczno-spo-

\footnotetext{
${ }^{17}$ W. Rzońca, Norwid a romantyzm polski, s. 222.

${ }^{18}$ Por. A. M. Frankowiak, Być wśród żywych i umartych, s. 27.

${ }^{19}$ T. Olejnik, O Polsce, Rosji, Europie $i$ wolności. Zygmunt Krasiński w świadomości drugiej emigracji, [w:] Zygmunt Krasiński. Nowe spojrzenia, red. G. Halkiewicz-Sojak, B. Burdziej, Toruń 2001, s. 529.

${ }^{20}$ Por. J. Kleiner, Krasiński, [w:] tegoż, Zygmunt Krasiński. Studia, Warszawa 1998, s. 49 58 oraz tegoż, [Nie-Boska komedia], [w:] tamże, s. 129-150.
} 
łecznych ${ }^{21}$, co zmusza do odczytywania dzieła w specyficznej tonacji. Sam autor przypomina, że bierze $\mathrm{w}$ nawias dotychczasowe interpretacje, zgodnie $\mathrm{z}$ jego słowami, „akademickiej krytyki literackiej” [s. 410], którą w tym przypadku reprezentuje Józef Ujejski. W końcu „Praktyka [...] wykazuje, że szczególnie żywe są dzisiaj te ustępy z Nie-Boskiej, w których Krasiński analizuje niebezpieczeństwo istniejące potencjalnie w e w ną tr z obu walczących o okopy Świętej Trójcy obozów” [s. 407-408].

Tym samym Herling zaznacza, że: „Jest [...] krzywdzącą Krasińskiego pochwałą przypisywanie mu tylko wieszczenia nadchodzącej rewolucji społecznej" [s. 408]. Chociaż pisarz informuje, że utwór można tak odebrać, jak czyni między innymi przywoływany przez niego G. K. Chesterton, to jednak kwestia ta po zakończeniu drugiej wojny światowej nie jest najistotniejsza. Zauważmy jeszcze, że Herling „racjonalizuje” wieszczy charakter przenikliwego pióra Krasińskiego. Autor wylicza, iż trafne przewidywania opinogórskiego hrabiego nie wynikały z siły poezji, ale z racjonalnych pobudek: „[Krasiński], który działał w okresie ciągle ponawiających się wrzeń socjalnych, który odbierał od swego przyjaciela Reeve'a listy o krwawym strajku w fabrykach jedwabiu w Lionie i o pierwszych odruchach niezadowolenia wśród robotników w Anglii” [s. 408]. Z podobną tezą wystąpił przywoływany Kleiner: „Nie-Boska nie jest proroctwem - jest ona sądem poetyckim i socjologicznym, przez ogrom horyzontu i potęgę prawdy może jedynym w poezji" ${ }^{22}$. Takie przedstawienie genezy dramatu obdziera romantyzm z łączonego $\mathrm{z}$ tą epoką daru spojrzenia w przyszłość, co wpisuje się w Herlingowską polemikę z epoką Mickiewicza.

Tak więc dla Herlinga znacznie ciekawszy i bardziej związany z aktualnymi wydarzeniami wydaje się szczegółowy opis rewolucjonistów i arystokracji dokonany przez Krasińskiego. Jak deklaruje eseista: „Istotną i nieprzemijającą wartością Nie-Boskiej komedii jest więc raczej nieprzeciętna zdolność widzenia produktów uboczny ch każdej rewolucji społecznej” [s. 408]. Herling podkreśla, że rewolucyjnym ruchom społecznym „towarzyszą nieodłącznie procesy rozkładowe”, które „w ostatecznej próbie sił $[\ldots]$ znacznie gwałtowniej zwracają się przeciwko obrońcom »starego porządku« niż przeciwko jego przeciwnikom" [s. 408-409]. Owe procesy rozkładowe są jednak inne dla każdego z obozów. Dla rewolucjonistów oznacza to przede wszystkim „niebezpieczeństwo »stanu czwartego«" [s. 409], co też zostaje poparte słynnym komentarzem hrabiego Henryka na temat Blanchettiego: ,„Radzę wam, go zabijcie, bo tak się poczyna każda arystokracja «" [s. 408]. Jednocześnie Herling sugeruje, iż odpowiednikami dowódcy z Nie-Boskiej komedii są marszałkowie sowieccy. Można powiedzieć, że historia przyznała rację pesymistycznemu spojrzeniu późniejszego diarysty.

Herling uważa również, że „bardziej przenikliwa jest analiza obozu broniącego Okopów Świętej Trójcy" [s. 409] (co oczywiście nie wyklucza aprobaty odnoszącej się do opisu zwolenników Pankracego). Tutaj autor stwierdza, że produktem ubocznym w obozie arystokracji jest zdrada, i ponownie czyni analogię z teraźniejszością: „Ta prawdziwa wylęgarnia Quislingów, z której jak grzyby po deszczu wynurzają się małoduszni i tchórzliwi sprzedawczykowie tego wszystkiego, co stanowiło kiedyś o ich potędze i znaczeniu, napełnia czytelnika szczerym obrzydzeniem" [s. 408]. Nawiązanie

\footnotetext{
${ }^{21} \mathrm{Na}$ uwagę Boleckiego, że „pisarstwo krytyczne” Herlinga po 1945 r. nabiera innego charakteru, nie dotyczy już tylko najnowszych publikacji, sam pisarz odpowiada: „I nie były to już teksty czysto literackie. [...] Pisałem coraz więcej szkiców, które były już czymś więcej niż recenzjami, jakkolwiek opierały się na konkretnych książkach”. Por. G. Herling-Grudziński, W. Bolecki, Rozmowy w Dragonei, s. 305.

22 J. Kleiner, [Nie-Boska komedia], s. 130.
} 
do norweskiego kolaboranta każe zwrócić uwagę na te ustępy Nie-Boskiej, w których kolejni przedstawiciele arystokracji poddają się Pankracemu, co hrabia Henryk podsumowuje w gorzkich słowach: „klęcząc wyciągają ramiona ku zwycięzcom i bełkocą o miłosierdzie!’’23. Pytaniem otwartym pozostaje, czy Herling w ten sposób pośrednio ostrzega rodaków np. przed ugodowością wobec komunistów. Oznaczałoby to jednak utożsamienie Polaków z obozem arystokracji, co w kontekście całego eseju Herlinga wiązałoby się ze zbytnią swobodą interpretacyjną. Poprzestańmy zatem na stwierdzeniu, że autor wyraża tutaj dezaprobatę dla zdrajców na poziomie wybiegającym daleko poza ramy podziałów społeczno-politycznych, kiedy zdradę postrzega się w kategoriach uniwersalnych. W końcu dla autora niezwykle istotne jest zachowanie „postawy wyprostowanej" nawet $\mathrm{w}$ sytuacjach skrajnych ${ }^{24}$. Dla pisarza stanowi to z pewnością kluczowe zagadnienie; zostało ono poruszone już wcześniej, w motcie, zajmującym ważne miejsce w konstrukcji tekstu. Przywołany został fragment rozmowy Henryka z Pankracym, w której ten ostatni namawia arystokratę do przyłączenia się do rewolucjonistów. Jako odpowiedź można potraktować mieszczące się również w motcie słowa z poematu Scytowie Aleksandra Błoka. Te dwie wypowiedzi pokazują, jak trudno oprzeć się propozycji dołączenia do antagonistów. Hrabia Henryk z tej próby wychodzi zwycięsko, co jednak nie oznacza, że staje się ulubionym bohaterem Herlinga. Jak zaznacza pisarz: „walczył do końca tylko w imię sprawy tak społecznie obojętnej jak... poezja" [s. 408]. Taka przyczyna podjęcia skądinąd właściwej decyzji nie spotyka się z uznaniem autora - nie przynosi wymiernych korzyści, a także wiąże się z wynaturzeniami romantyzmu. Później jeszcze spotkamy się z ironiczną uwagą na temat śmierci bohatera, która zgodna jest z „obyczajem romantycznym” [s. 411].

Pozytywna ocena opisu antagonistów nie oznacza wcale podziwu dla erudycji autora Nie-Boskiej w przedstawianiu dwóch odmiennych światopoglądów reprezentowanych przez postacie Henryka i Pankracego. Herling stawia zaskakującą tezę, że tak naprawdę nie mamy do czynienia ze starciem wielkich myśli, tj. chrystianizmu oraz opartego na tradycji idealizmu przeciwko antychrześcijańskiemu materializmowi ${ }^{25}$. Uważa, że problematyka dzieła nie ma w zasadzie charakteru filozoficznego, a bardziej przyziemny, związany z rywalizacją klas społecznych. Pisarz gotów jest nawet zlekceważyć zdanie autora o własnym utworze, sprowadzić je do opinii o uczniu, który treść lektury zna wyłącznie z opracowania. Nie zgadza się zatem z autorską tezą, że NieBoska to obrona przeszłości. Według emigranta „trudno o lepszy przykład zbanalizowania własnego dzieła na rzecz gustów »dobrze wychowanego« czytelnika” [s. 409]. Rozważania te są posunięte znacznie dalej, pojawia się wręcz sugestia, że autor Irydiona celowo wskazywał na fałszywą problematykę własnego utworu: „Jestem zdania, że Krasiński był sam zaskoczony swą wizją poetycką i próbował ją osłabić nie tylko w epilogu, ale i w osobiście głoszonych komentarzach [...] Krasiński analizuje w NieBoskiej konflikt klas społecznych, a pragnie go rozwijać jako konflikt światopoglądów" [s. 409-410]. Ta próba wejścia w psychikę wieszcza zostaje wsparta interesującą argumentacją z Filozofii romantyzmu polskiego Brzozowskiego. Pisarz doby Młodej Polski mówi, że w ,„»stosunku [Krasińskiego - A. W.] do ideału romantycznego, do prawdy przez romantyków objawionej jest głęboka rozpacz niemocy, ale jest też coś

${ }^{23}$ Z. Krasiński, Nie-Boska komedia, [w:] tegoż, Dzieła literackie, wybrał, notami i uwagami opatrzył P. Hertz, t. 1, Warszawa 1973, s. 412

${ }^{24}$ Por. np. G. Herling-Grudziński, Dziennik pisany noca, t. 1 (1971-1981), Kraków 2011, s. 286.

${ }^{25}$ Por. J. Kleiner, [Nie-Boska komedia], s. 142. 
z sadyzmu intelektualnego«" [s. 410]. Zdanie kontrowersyjne, aczkolwiek przez Herlinga akceptowane.

Eseista tym samym nawet nie tyle aktualizuje wymowę utworu, co wskazuje, że owe wątki klasowe, ważne również w latach 40. minionego stulecia, od samego początku powinny być dostrzegalne dla czytelnika. Herling głosi tutaj poglądy, które we wstępie do Ksiag... Mickiewicza zostaną przekształcone w wyrazisty postulat działania na rzecz „uspołecznienia narodu”. W lekturze Krasińskiego autor docenia, że poeta, w końcu przedstawiciel myśli konserwatywnej związanej z arystokracją, dołożył wszelkich starań, aby jak najstaranniej zaprezentować racje strony rewolucyjnej. Przytoczmy dłuższy cytat, który pozwoli nam lepiej zrozumieć „,propozycję dyskusyjną” Herlinga nad Nie-Boska komedia:

Wszystko to [...] jest przekonywającym i z pasją przez autora zebranym materiałem oskarżycielskim krzywdzonych przeciwko krzywdzicielom. Gdy się rozważa obiektywnie ciężar argumentów społecznych obu stron, to zdaje się nie ulegać wątpliwości, że mimo całej, odrażającej z pozoru, apokalipsy gniewu społecznego, jaka dławi za gardło ten ,pomiot rodzaju ludzkiego” zebrany w obozie Pankracego — jest on żywą i zdrową reakcją przeciwko małodusznemu egoizmowi klas posiadających [s. 410].

Jest to fragment obfitujący w szereg rozwiązań retorycznych, związanych z ostrą oceną nierówności społecznych dokonaną przez Herlinga. Takie sformułowania, jak „materiał oskarżycielski krzywdzonych przeciwko krzywdzicielom” czy „apokalipsa gniewu społecznego", sprawiają, że szkic nabiera agitacyjnego tonu manifestu politycznego. Autor wypowiada, jak w żadnym innym fragmencie eseju, swój sprzeciw wobec niesprawiedliwości wynikających z nadmiernych różnic klasowych. Herling nie kryje, która strona konfliktu jest mu bliższa, i co więcej, usprawiedliwia jej kontrowersyjne działania. Zbrodnie określa mianem pozornych, a przez przyrównanie sprzeciwu najbiedniejszych do wizji apokaliptycznych, wręcz uświęca tego typu postępowanie. Jak wyzwanie rzucone czytelnikowi brzmią słowa, że prowadzone rozważania są obiektywne. W końcu sam autor zastrzegał, że szkic ma stanowić zaledwie propozycję dyskusyjną, a w tym momencie przybiera zupełnie inny, bardzo wyrazisty ton. Jednak ów wyjątek z tekstu Herlinga pozwala na pewno lepiej zrozumieć poglądy społecznopolityczne autora. Jawi się on jako zwolennik socjalizmu, radykalnych przemian, oczywiście nie w wykonaniu komunistycznym, czemu dał wyraz, przyrównując oficerów sowieckich do Blanchettiego.

Być może to właśnie takie spojrzenie na obóz rewolucjonistów każe pójść eseiście jeszcze dalej w interpretacji Nie-Boskiej. „Prowokacyjną tezą tego artykułu jest, że zwyciężył nie Galilejczyk, ale Pankracy" [s. 409] — zaznacza autor, zdając sobie sprawę ze zdziwienia, jakie wywołuje taka teza. Oczywiście, podobnie jak wcześniejsi badacze, Herling sceptycznie odnosi się do samego pojawienia się Chrystusa. Jak zaznacza Kleiner: „Optymistyczne zakończenie stanowi dodatek nieograniczony”26; Herling idzie nieco dalej, mówiąc: „Zbyt nagłe i niespodziewane było to zwycięstwo Galilejczyka, abyśmy mogli w nie uwierzyć jako coś więcej niż w bezradny symbol" [s. 409]. Ponadto takie pośmiertne zwycięstwo hrabiego Henryka ,stanowi prawdziwie romantyczny zgrzyt w logicznie narastającej akcji utworu" [s. 409]. Przybycie Chrystusa w Nie-Boskiej w lekturze Herlinga jest tylko „poetyckim epilogiem”, który burzy wcześniejszą, misternie zaplanowaną konstrukcję.

Dlatego też późniejszy diarysta bez skrupułów odrzuca problematyczne zakończenie i stawia na analizę, która niweluje zasadność boskiej ingerencji w działanie ludzkie.

\footnotetext{
26 Tamże, s. 144.
} 
Na czym zatem miałoby polegać zwycięstwo Pankracego? Otóż Pankracy „zdobył »twierdzę tradycji« [...] zmusił ich [arystokratów - A. W.] do wyparcia się własnych ideałów życiowych" [s. 409]. Abstrahując od popierania wybranego przez Herlinga obozu, okazuje się, że dla autora porażka nie jest tożsama w pierwszej kolejności z utratą jakiejś korzyści, ale z wyrzeczeniem się, czy właściwie zdradą, wcześniej reprezentowanych ideałów. Tego typu zachowanie nie mieści się w Herlingowskiej sylwetce „człowieka wyprostowanego”. W ten sposób Pankracy odniósł sukces na poziomie idei; działania jego zwolenników doprowadziły do zasadniczego momentu, w którym arystokracja decydowała się, wbrew wcześniejszym zapowiedziom, na oddanie broni i złorzeczenie swojemu przywódcy — hrabiemu Henrykowi. Herling w pewnym sensie staje w obronie Pankracego; według niego bohater nie spodziewał się zwycięstwa i tylko stąd wynikają jego rozterki opisane w końcowej fazie dramatu. Herling decyduje się nawet na bardzo szerokie dywagacje, wręcz przeczące informacjom zawartym na łamach samego utworu: „Mamy wszelkie dane, aby przypuszczać, że to on [Pankracy - A. W.] dźwignie się raczej z ramion Leonarda (wbrew zapewnieniom poety, który powiada: »stacza się w objęcia Leonarda i kona«) niż Henryk” [s. 411]. Trafnie tę nietypową wizję Pankracego podsumowała Olejnik: „Dla Grudzińskiego Pankracy nie jest postacią tragiczną, uosabia on typowy dla każdej rewolucji kryzys wywołany nienadążaniem obiegu idei za rozwojem wypadków, lecz jest to tylko chwila zawahania, moment słabości, nie zaś klęska bohatera"27.

Odrzucenie metafizycznego zakończenia Nie-Boskiej komedii związane jest z jeszcze jednym istotnym postulatem, który opiera się na poglądach społeczno-politycznych autora szkicu. Podobnie jak w przypadku rozważań powstałych na marginesie lektury listu Norwida oraz Ksiag... Mickiewicza, na plan pierwszy zostaje wysunięty program postawy aktywnej. Herling, powołując się na Brzozowskiego, przekonuje, że Krasiński usprawiedliwia swego rodzaju inercję właśnie przez sugerowanie zwycięstwa Galilejczyka: „A ten, który »stoi niewzruszony — trzy gwoździe, trzy gwiazdy na nim ramiona jak błyskawice«, pozostaje jako symbol »prawdy, przekształconej tak, aby bierność, wyrzeczenie się czynu wydawały się konsekwencjami, wypływającymi z niej, przez nią usprawiedliwionymi«" [s. 411]. Chociaż Chrystus pozostaje prawdą, to jednak owa prawda w dramacie zostaje ,przekształcona” w tak niepożądany sposób, że, jak zauważa przytoczony przez eseistę Brzozowski, z idei ,»ulatnia się [...] pierwiastek ziemski: obowiązek czynu «" [s. 410]. Oczywiście to spostrzeżenie tyczy się wyłącznie słynnego dramatu; wiadomo przecież, że Krasiński stanie się jednym z głównych propagatorów filozofii czynu, ale dopiero za kilka lat nawiąże korespondencję z Cieszkowskim i wtedy też usystematyzuje swoje poglądy ${ }^{28}$. Tak więc końcowy postulat Herlinga związany jest przede wszystkim z odrzuceniem symbolicznego zakończenia dramatu. Autor docenia Krasińskiego za wartościowe nakreślenie różnic klasowych, niemniej wadą utworu pozostaje zakończenie, co oznacza przerost symboliki nad realnym znaczeniem (,ze śmiertelną wiernością ukochany mit przeciwstawia się faktom" [s. 412]). W tym też eseista widzi problem całej polskiej literatury — nieustanna symbolika, która najpierw oznacza hrabiego Henryka rzucającego się w przepaść, a wiek później - Barykę, który podąża z tłumem na Belweder. Według emigranta zyskujemy wtedy jedynie szereg „groźnych znaków zapytania” [s. 412], co jest rów-

${ }^{27}$ T. Olejnik, O Polsce, s. 529.

${ }^{28}$ Por. np. A. Kowalczykowa, Poglady filozoficzne Zygmunta Krasińskiego, [w:] Polska myśl filozoficzna i spoteczna, red. A. Walicki, t. 1, Warszawa 1973, s. 306. 
noznaczne z próbą uniknięcia oczywistych odpowiedzi. Dla takiej literatury na półce Herlinga nie ma miejsca.

\section{Herling-Grudziński a Mickiewicz}

Nieco wcześniej niż będący przedmiotem naszego zainteresowania szkic „Księgi narodu i pielgrzymstwa polskiego" na nowej emigracji ukazał się w "Orle Białym” esej Mickiewicz w Rzymie i w Moskwie. Ciekawe odkrycie literackie. Nie zajmujemy się nim tutaj szczegółowo, zamieszczone tam przemyślenia na temat wieszcza dotyczą jego życia prywatnego i nie są osnute wokół dzieł Mickiewicza. Mimo to warto przedstawić konkluzję tego tekstu, gdyż może ona okazać się pomocna, aby zrozumieć datowane na później rozważania o Ksieggach..., a zwłaszcza stosunek dwudziestowiecznego emigranta do autora Dziadów. Herling przypomina w szkicu przyjaźn Mickiewicza z rosyjską księżną Zeneidą Wołkońską, która została zerwana z inicjatywy Polaka. Eseista spostrzega, że „zdarzenie to może być nie bez racji również uważane za literacką story na aktualne tematy polityczne” [s. 314], ponieważ „Może nie potrafiła [księżna - A. W.] nawet zrozumieć nigdy, że wspomnienie niewoli kopie przepaści nie do przebycia nawet pomiędzy ludźmi wolnymi w duchu?" [s. 313]. W tym pytaniu skonstruowanym na zasadzie gorzkiej ironii z łatwością można odczytać, dlaczego stosunek Herlinga do Mickiewicza podczas pisania wstępu do wskazanego dzieła wybitnego romantyka okaże się momentami tak trudny. Mickiewicz jawi się Herlingowi jako ten, który wszystko podporządkowuje sprawie narodowej. Podkreślmy przy tym, że w eseju zamieszczonym w tygodniku próżno szukać potępienia wieszcza, który nie jest w stanie oddzielić działalności patriotycznej od apolitycznej przyjaźni. Herling rozumie, jak skomplikowana może być miłość do narodu, czemu da znać w 1946 roku, pisząc właśnie wstęp do dzieła Mickiewicza.

Owszem, już we wcześniejszym tekście poświęconym Norwidowi autor nakreśla główne wytyczne dla nowej emigracji polskiej, wskazuje też na podstawowe mankamenty związane z przyjmowaniem paradygmatu romantycznego. Jednak wstęp do Ksiag..., chociaż rozbudowuje w znacznym stopniu myśl Herlinga z 1944 roku, pełni ważniejszą funkcję, stanowi bowiem pełnoprawny manifest drugiej emigracji. Wskazuje na to sam Jerzy Giedroyc: „naprawdę ważne były dla nas wtedy książki. [...] Dwie pozycje na tej liście miały charakter programowy: Księgi narodu polskiego i pielgrzymstwa polskiego Mickiewicza, które ze względu na zasadniczy wstę p [podkr. A. W.] Gustawa, były naszym manifestem, oraz Prometeusze Stanisława Szpotańskiego"29. Jednoznaczne określenie charakteru wydawnictwa, które ukazało się tuż po zakończeniu wojny w nowo utworzonym Instytucie Literackim, udowadnia wzniosłe zadanie, z jakim musiał zmierzyć się wówczas Herling. Pisarz zdawał sobie z tego sprawę; po latach wspominał: „Uważałem emigrację za rodzaj misji, a samo pozostanie na emigracji za rzecz pierwszorzędnej wagi i od pierwszej chwili nie miałem co do tego żadnych wahań" ${ }^{30}$. Autor „zasadniczego wstępu” w jakimś sensie wpływał na kształt powojennej emigracji ${ }^{31}$. Poprzez wstęp otwierał nowy rozdział w historii Polski,

${ }^{29}$ J. Giedroyc, Autobiografia na cztery ręce, oprac. i posł. opatrzył K. Pomian, Warszawa 1994, s. 126.

${ }^{30}$ G. Herling-Grudziński, W. Bolecki, Rozmowy w Dragonei, s. 310.

${ }^{31}$ Kudelski w swoich wnikliwych studiach o autorze przypomina, że Księgi... wraz ze wstępem Herlinga ukazały się również na emigracji krótko po wprowadzeniu stanu wojennego w Polsce, co też raz jeszcze potwierdza doniosłość wydawnictwa. Por. Z. Kudelski, Studia o Herlingu-Grudzińskim, s. 39. 
w której „pielgrzymstwo” co najmniej od dziewiętnastego stulecia zajmowało bezprecedensową pozycję. Dlatego też nie dziwi, że wstęp do Ksiag... oscyluje nie tylko wokół Mickiewiczowskiego katechizmu; niejednokrotnie stanowi on zaledwie początek szerszych, choć nadal odnoszących się do romantyzmu, rozważań.

Bezpośredni zarzut, jaki Herling stawia Mickiewiczowi, związany jest z okolicznościami powstania utworu. Podobnie jak w przypadku Krasińskiego, tak i teraz młody literat nie zgadza się na opinię „uniwersyteckich komentatorów”, w tym wypadku dotyczącą właśnie genezy dzieła, zgodnie z którą Księgi..., w znaczeniu metaforycznym, ,miały zapobiec bankructwu emigracji” [s. 472]. Te wyjaśnienia autor określa wyłącznie jako „częściowo tylko słuszne” i zaznacza, że „Księgi są także zdumiewająco prostym wyrazem polskiej reakcji p o k 1 ę s k o w e j" [s. 472]. Kontynuując tę myśl, autor dopowiada, że „Mickiewicz wyszedł [...] naprzeciw wiecznie w duszy polskiej żywemu pragnieniu wythumaczenia się z klęski” [s. 473]. Reasumując: dla dwudziestowiecznego emigranta autor Dziadów jest jednym z głównych budowniczych „filozofii klęski”. W ten sposób Herling stawia pod dużym znakiem zapytania obraz historii zaprezentowany na łamach Ksiag..., który przyczyny utraty niepodległości widzi w dużej mierze w działaniach państw sąsiednich. Eseista mówi o wzbudzaniu ,poczucia tragizmu” wynikłym z „położenia politycznego Polski” [s. 473], co możemy odczytać jako potępienie sprowadzania klęski do działań, posługując się określeniem Mickiewicza, „trójcy szatańskiej”. Herlingowi nie odpowiada eschatologiczny charakter dziejów Polski zaproponowany przez wieszcza ${ }^{32}$. Wnioskując $z$ wywodów pisarza, a zwłaszcza przytoczonych powyżej ironicznych słów o „pragnieniu” usprawiedliwienia klęsk, stwierdzamy, że autor dostrzega niebezpieczeństwo w poszukiwaniu ich przyczyn jedynie w działaniach zewnętrznych, na które nikt nie ma wpływu.

Oczywiście nigdzie nie jest powiedziane, że Herling za nieszczęścia narodowe wini tylko Polaków. Domaga się jednak głębszej, bardziej krytycznej refleksji, na co wskazuje przywołanie słynnej myśli Norwida: „»Kraj, gdzie każdy czyn za wcześnie wschodzi, ale książka każda za późno «". Słowa te stanowią „najlepszy, choć i najbardziej surowy, komentarz do utworu Mickiewicza” [s. 472-473]. Owa „książka” w tym kontekście to nic innego, jak metafora brakującego, a przecież tak potrzebnego namysłu przed podjęciem ryzykownych działań. Herling zatem pozostaje wierny Norwidowi i jego postulatom, które kilkanaście miesięcy wcześniej szkicował w eseju zamieszczonym w Żywych i umarlych.

Jak sygnalizowaliśmy, wstęp do Ksiag... Herlinga nie dotyczy tylko spostrzeżeń oscylujących wyłącznie wokół dzieła z 1832 roku, mimo że to właśnie jego lektura skłania do rozpatrzenia innych zagadnień związanych $\mathrm{z}$ epoką romantyczną, w tym wypadku — z mesjanizmem. Herling, snując refleksje nad „, z t e r e ma z a s a d n ic zymi jarzmami, które na nowej emigracji musimy z siebie za wszelką cenę zrzucié” [s. 475], nie czyni zbyt wielu aluzji do „broszurki” Mickiewicza; swoje zarzuty odnosi raczej do powszechnych odczytań założeń romantyzmu. Kategorią „,mesjanizm" pisarz posługuje się w szerokim tego słowa znaczeniu; nie chodzi wyłącznie o mesjanizm w powiązaniu ze szczególnym zadaniem danego narodu, analogicznym do misji Chrystusa ${ }^{33}$. U Herlinga słowo to widnieje jako pewna figura, która gromadzi w sobie wszelkie negatywne cechy powstałe w ramach epoki, które pisarz usilnie zwal-

\footnotetext{
${ }^{32}$ Por. Z. Stefanowska, Historia i profecja. Studium o „Księgach narodu i pielgrzymstwa polskiego" Adama Mickiewicza, Warszawa 1962, s. 73.

${ }^{33}$ Por. np. S. Pieróg, hasło: Mesjanizm, [w:] Stownik literatury polskiej XIX wieku, red. J. Bachórz, A. Kowalczykowa, Wrocław 2009, s. 536-537.
} 
cza. Zrozumiałe zatem staje się, dlaczego Jacek Breczko zalicza Herlinga do ,antymesjanistów analitycznych" ${ }^{34}$. Autor wstępu jednocześnie nie neguje filozoficznej wartości mesjanizmu polskiego jako oryginalnego wkładu w myśl europejską. Co więcej, potrafi dostrzec jego niewątpliwe zasługi: „Mesjanizm nauczył Polaków religii narodu, wraz z całą jej liturgią i praktyką. Ma więc duże zasługi, gdyż miłość ojczyzny w czasach, gdy »naród nie istnieje jako państwo«, przybiera zawsze formy wiary, zabarwionej na sposób religijny" [s. 475]. Problem zaczyna się dopiero wtedy, gdy mesjanizm opuści pole teoretycznych rozważań i wstąpi „na poziom odczuwania powszechnego” [s. 475].

O ile w eseju o Norwidzie autor domagał się publikacji dotyczącej kondycji polskiej inteligencji, o tyle teraz zarysowuje potrzebę kolejnej analizy: „Studium o mesjanizmie, o gruntownie rewizjonistycznym i nowoczesnym podejściu do pojęcia, które spętało całe pokolenia Polaków, dając im religię Ojczyzny jako zastępczą namiastkę walki o nią, byłoby zapewne najlepszą formą skończenia $\mathrm{z}$ urokiem rzeczy przedawnionych, a mimo to nieustannie działających" [s. 474]. W przytoczonym fragmencie zwracają uwagę takie określenia, jak „spętało” oraz „urok”. Herling z niepokojem stwierdza, że Polska została wciągnięta w ramy określonego paradygmatu, który w tym przypadku wiąże się z tak obcą mu przecież postawą pasywną. Ponadto autor występuje z propozycją „nowoczesnego podejścia” do mesjanizmu — w końcu druga wojna światowa wytyczyła wyrazistą cezurę, był to czas obejmujący wydarzenia wcześniej niespotykane, do których zrozumienia nie są odpowiednie rozwiązania sprzed ponad stulecia. Eseista w pewnym sensie dostrzega tragizm sytuacji: mimo nieprzystawalności dziewiętnastowiecznych ujęć są one jednak wciąż obecne w myśleniu Polaków. Niepokoi go swoista ufność w cykliczność historii: „prawie każdy Polak, żyjąc w atmosferze wolności, uważał Państwo za świętość, z jej pozbawieniem nie przestaje ufać, że rzeczy święte zmartwychwstają" [s. 474]. Według Herlinga ewentualne odzyskanie suwerenności po drugiej wojnie światowej nie będzie tożsame z wydarzeniami 1918 roku. Po raz kolejny zostaje podkreślona niepowtarzalność sytuacji, a jednocześnie, pośrednio, zwraca się uwagę na specyfikę działań Związku Sowieckiego oraz Zachodu w stosunku do Polski. Tym samym takie analogie, powroty do przeszłości, choć bardzo kuszące, zostają przez Herlinga odrzucone, co trafnie scharakteryzował Mencwel w analizie wstępu do Ksiag...: „,czas historyczny naprawdę nie jest pusty i powtórzeniami się nie wypełnia. Jest on realnością doświadczeń i działań kolejnych pokoleń, a są to pokolenia duchowo i społecznie zmienione, dla których Mickiewiczowskie posłanie jest pouczające, a nie obligujące" ${ }^{35}$. Herling w ten sposób przestrzega przed emigracyjną biernością. Jak zauważa Bolecki: „W dążeniu do rewizji podstaw narodowej psychiki autor $\dot{Z} y$ wych i umarlych zbliżał się wówczas do koncepcji, które najpełniej rozwinie Witold Gombrowicz"36.

Na cztery „zasadnicze jarzma”, czy też, według Frankowiak, schematy ${ }^{37}$, składają się, wielokrotnie przytaczane przez badaczy twórczości Herlinga: „indywidualizm romantyczny”, „megalomania narodowa”, „rewolucyjność alkowiana” oraz „czar wawelski”. I chociaż owe grzechy zostały wyodrębnione i omówione z należytą uwagą

${ }^{34}$ J. Breczko, Poglądy historiozoficzne pisarzy z kręgu „Kultury” paryskiej. Przezwyciężenie katastrofizmu, odrzucenie mesjanizmu, Lublin 2010, s. 490.

${ }^{35}$ A. Mencwel, Przedwiośnie czy potop. Studium postaw polskich w XX wieku, Warszawa 1997, s. 278.

${ }^{36}$ W. Bolecki, Ciemny staw. Trzy szkice do portretu Gustawa Herlinga-Grudzińskiego, Warszawa 1991, s. 18.

${ }^{37}$ Por. A. M. Frankowiak, Być wśród żywych i umartych, s. 29. 
osobno w części „Studium o mesjanizmie”, to Herling w całym wstępie do Ksiag... niejednokrotnie do nich nawiązuje i naświetla „cztery jarzma” z różnych stron.

Jako pierwsze zostaje wymienione jarzmo indywidualizmu romantycznego. Herling zdecydowanie przeciwstawia dzisiejsze rozumienie indywidualizmu temu romantycznemu, który - podkreślmy - eseista postrzega dwojako. Indywidualizm tamtej epoki wiąże się ze zwrotem ku sobie, afirmacją świata wewnętrznego. Badacze akcentują, że tak indywidualizm rozumiano zaledwie w pierwszej fazie romantyzmu, później nastąpiło otwarcie na zbiorowośćc ${ }^{38}$, jednak powojenny emigrant już tego nie dostrzega. Co więcej, według niego polski indywidualizm romantyczny oznacza, że jednostka, jakkolwiek to zabrzmi, sama w sobie jest narodem (,Każdy Polak to »mały naród«" [s. 476]). Autor ogłasza zatem, że „,indywidualizm romantyczny ma niewiele wspólnego z normalnym poszanowaniem praw rozwojowych jednostki. Współczesna myśl europejska poczyniła ważne rozróżnienie pomiędzy takim humanizmem, który uważa człowieka za ośrodek każdego działania, i takim, dla którego człowiek jest celem tego wszystkiego, co sam czyni” [s. 475]. Z kolei dalej mówi się, że „człowiek ma prawo do zupełnej swobody w wypadku, gdy jej używa dla udoskonalenia siebie samego, włączonego w system jakichś wyższych wartości” [s. 475]. Takie słowa w ustach autora Innego świata nie dziwią. Badacze niejednokrotnie podkreślali afirmowanie przez Herlinga postaw niezłomnych, związanych z nieskazitelną postawą moralną, wzorowaną na prozie Conrada i Dostojewskiego ${ }^{39}$. Romantyzm oczywiście daje taką wartość, jednak eseista nie może się na nią zgodzić, skoro jest nią naród mieszczący się, zgodnie $\mathrm{z}$ terminologią autora, w ramach „filozofii klęski”.

Podczas rozważań nad genezą Ksiag... emigrant czyni uwagę, do której w tym momencie warto powrócić: „Mistyczny znak równania, położony między narodem i jednostką, był znakiem siły i bezsilności jednocześnie" [s. 473]. Do poprawnego odczytania tych słów konieczne staje się zrozumienie Herlingowskich założeń, jakie muszą przyświecać walce o wolność ojczyzny. Według niego wiara $\mathrm{w}$ jakąs idę powinna być nierozerwalnie związana z walką (co jest zgodą na uwagę Mickiewicza, że „żołnierz, który walczy bez wiary w dobroć sprawy swojej, zwierzem jest" ${ }^{\text {"40 }}$ ), czyli postawą aktywną, a zatem dającą rezultaty „na zewnątrz”. Jednak walka, zarówno w latach 30. XIX wieku, jak i w 1945 roku zakończyła się klęską, co też oznacza, że „Człowiek [...] który uszedł z pola walki, świeżo pokonany, może już tylko wierzyć" [s. 473], a wtedy jednostce pozostaje wyłącznie ,czynne życie zastąpić dążeniem do moralnej doskonałości” [s. 474]. A jako że „Każdy Polak to »mały naród « lub »naród w miniaturze«" [s. 476], zanik walki zewnętrznej zostaje zarazem znakomicie usprawiedliwiony, ponieważ walka o naród w takim rozumowaniu może się przecież toczyć tylko ,wewnątrz" jednostki (skoro jednostka tożsama jest z narodem). Natomiast dla Herlinga ów czyn nie może być związany tylko ze sferą duchowych przemian wewnętrznych, gdyż oznacza to zaniechanie czynu „na zewnątrz”, a zatem stanowi bierną postawę i zapewne łatwe wytłumaczenie niemocy względem działań społeczno-politycznych. Dlatego też autor używa mocnych słów wobec swoiście definiowanego indywidualizmu romantycznego, który „stał się bardzo szybko wyrazem samowoli i głupoty, zarozumialstwa i pychy” [s. 476]. Herling, jako zwolennik „uspołeczniania narodu”, musi

${ }^{38}$ Por. H. Krukowska, hasło: Indywidualizm, [w:] Stownik literatury polskiej XIX wieku, s. $365-369$.

${ }^{39}$ Por. np. K. Pomian, Herling-Grudziński - emigracja heroiczna, [w:] Herling-Grudziński $i$ krytycy, s. 31 oraz A. M. Frankowiak, Być wśród żywych i umartych, s. 27.

40 A. Mickiewicz, Ksiegi narodu polskiego i pielgrzymstwa polskiego, [w:] tegoż, Dzieła, t. V: Proza artystyczna i pisma krytyczne, tom oprac. Z. Dokurno, Warszawa 1999, s. 49-50. 
zrezygnować z tego typu „etyki indywidualnej” (związanej z rozumieniem „romantycznego" narodu jako wartości nadrzędnej), gdyż jest to równoznaczne z podniesieniem ,środka [tj. dążenia do moralnej doskonałości - A. W.] do miary samodzielnej wartości” [s. 474], czyli, powtórzmy raz jeszcze, odrzuceniem jakichkolwiek działań (zewnętrznych). Tym samym esej Herlinga oznacza wielki sprzeciw (ponieważ grozi to całkowitym wycofaniem się jednostki do „wewnątrz”) wobec przypowieści zamieszczonych w dziele Mickiewicza, które „wskazują na obowiązek jednostki wobec narodu jako na naczelną zasadę moralną"41. Na koniec tej części rozważań, aby rozwiać ewentualne wątpliwości, zaznaczmy, że Herling nie ma nic przeciwko dążeniu do doskonałości moralnej — uważa jednak, że postawienie na naród jako na naczelną wartość tak naprawdę przeszkodzi w wewnętrznej przemianie.

Kolejne przedstawione jarzma to w zasadzie rozwinięcie już wcześniej zamieszczonych we wstępie spostrzeżeń, które teraz ponownie powtórzone, nie oznaczają nic innego, jak chęć ich mocniejszego zaakcentowania. W końcu sam Herling mówi, że „Megalomania narodowa związana jest [... z indywidualizmem romantycznym” [s. 476], w podobnym tonie wyrazi się o „rewolucyjności alkowianej” i dlatego też wydaje się, że najwłaściwiej będzie mówić o tych jarzmach niejako jednocześnie.

W obu tych punktach najczęściej pojawia się problem cierpienia, które w pierwszym przypadku prowadzi właśnie do „grzechu” megalomanii narodowej. Herling z ironią - a może nawet z szyderstwem — odnosi się do dziewiętnastowiecznej polskiej polityki emigracyjnej, która uważała, że „miarą wielkości jest męka ukrzyżowania!..." [s. 476]. Za szczególnie niebezpieczne uchodzi tutaj zwłaszcza przyrównywanie dziejów Polski do męczeństwa Chrystusa. Autor wstępu po raz kolejny nie uznaje tak łatwych usprawiedliwień, a zarazem, odnosząc się także do czasów sobie współczesnych, krytykuje Polaków za nieznajomość twardych reguł gry politycznej: „,polska megalomania narodowa wychodzi ze złudnego założenia, że wartość poświęcenia i ofiary oceniana jest w świecie kryteriów politycznych i społecznych tą samą miarą, co w świecie norm moralnych" [s. 476]. Tym samym pośrednio sugeruje zmianę podejścia do obrony swoich praw na arenie międzynarodowej: Herling doskonale wie, że powoływanie się na dawne zasługi Polski, a tym bardziej stawianie się w prymarnej pozycji ze względu na zrównanie z losami Chrystusa, po 1945 roku nie odniesie żadnej rzeczywistej korzyści.

Wróćmy jednak do problemu cierpienia, który nie tylko decyduje o polskiej megalomanii narodowej, lecz także stanowi główny trzon ,grzechów” polskiego mesjanizmu, czyli rewolucji alkowianej ${ }^{42}$. Autor rozwija poprzednią myśl, po raz kolejny powtarza, że emigranci polscy wierzą w kuriozalną zasadę, iż ,»cierpienie rentuje się samo« i samo również zmienia istniejący stan rzeczy" [s. 477]. Tym razem Herling nie ukrywa drwiącego tonu i jawnie kpi z takiej interpretacji cierpienia. Dla podkreślenia swojej dezaprobaty używa szeregu określeń nieprzystających do trywialności przesadnie rozbudowanej w opisie sytuacji: „Kiedy zaś [Polak - A. W.] cierpi z racji niesprawiedliwości społecznej w czterech ścianach swego pokoju, to wydaje mu się, że ociekające krwią strzępy jego cierpienia wybuchają automatycznie za oknami jak bomby, burzące stary i szczerze dlań zresztą nienawistny porządek społeczny" [s. 477]. Zwalcza się w ten sposób ową tezę o zyskach wynikających z cierpienia, co trafnie ujął Mencwel, kiedy referował tę myśl Herlinga: „Historyczna tragedia nie jest oznaką

${ }^{41}$ Z. Stefanowska, Historia i profecja, s. 175.

${ }^{42}$ Według Mencwela termin ten jest „niezbyt zręcznym” nazwaniem kwietyzmu cierpienia. Por. A. Mencwel, Przedwiośnie czy potop, s. 278. 
predestynacji, cierpienie nie jest poręką rezurekcji, narody nie są ciałami mistycznymi, a osoby nie sa $\mathrm{z}$ nimi tożsame. Takie zrosty mentalne sa nie tylko błędne, ale i niebezpieczne" ${ }^{\natural 3}$. Emigrant jest wielkim przeciwnikiem takiego sposobu myślenia, co więcej, nie uważa, aby cierpienie było niezbędnym składnikiem ludzkiej egzystencji. Jak przypomni kilkadziesiąt lat później w rozmowie z Boleckim: „Nie należę do ludzi, którzy w cierpieniu dostrzegają jedynie katharsis. Cierpienie może być oczyszczające, ale to nie jest reguła, a raczej wyjątek. W każdym razie, moim zdaniem, cierpienie nie jest próbą, która wpływa korzystnie na osobowość ludzi" ${ }^{\text {"4 }}$. Tak też i w analizie Mickiewiczowskich Ksiag... - afirmacja cierpienia prowadzi do niepożądanej bierności i należy skończyć z tego typu podejściem, co jednak może okazać się wyjątkowo trudne. „Dalecy jeszcze jesteśmy od zmierzchu tego uroku wychowania romantycznego" [s. 477] — autor kończy pesymistycznie swój wywód.

Ostatnie z czterech jarzm zostało określone mianem „czaru wawelskiego”, który oznacza oczywiście „mediumiczne zapatrzenie się w dawną świetność, w groby królewskie, w wypłowiałe pamiątki narodowe" [s. 477]. Odniesienie do sfery spirytualnej (nawiązanie do medium) prowadzi do skojarzeń z powszechnie wyśmianymi seansami, które wiążą się z wywoływaniem rzekomych duchów przodków. Według Herlinga podobnie jest z Polakami i ich stosunkiem do przeszłości. Emigranci, posłużmy się metaforą, siedzą przy słynnych stolikach spirytualistów i oczekują na ratunek widm. Jednak owe widma nie istnieją, nie przyniosą oczekiwanej pomocy, a tego typu seans jest jałowy, wręcz komiczny, co już udowadniał Prus w Emancypantkach. Odnotujmy jeszcze, że jest to podobna figura retoryczna, jak wcześniejsze stwierdzenie, że mesjanizm rzucił na Polaków urok.

Co istotne, nie oznacza to, że Herling odrzuca tradycję czy też wykazuje się brakiem respektu wobec przeszłości. Tak daleko pisarz w swoich rozważaniach się nie posuwa. Jednakowoż uważa, że „mesjanizm, oparłszy całą swą filozofię na fałszywych przesłankach filozoficznych i moralnych, wykoszlawił również to uczucie, które w swej istocie nie jest przecież niczym innym, jak zdrowym i naturalnym przywiązaniem do tradycji narodowej" [s. 478]. Herling zatem występuje przeciw skrajnemu stanowisku afirmacji przeszłości, związanemu z wiarą w ,ślepy automatyzm tradycji”, która miałaby przynieść korzyść także teraźniejszości. Dla autora przeszłość jest nauczycielką życia, nie zaś hojnym ofiarodawcą niosącym ukojenie: „Wypadki historyczne [...] prawie zawsze uczą i zobowiązują. Współczesny więc Polak nie może być nędzarzem, okrywającym swą nagość strzępami płaszczów królewskich, ale tylko spadkobiercą i wykonawcą idei dziejowej państwa polskiego" [s. 478]. Historia określa pewne obowiązki, a więc nie powinna być odbierana jako pretekst do ukrycia się za zasłoną dawnej chwały. Nawet szaty królewskie ulegają zniszczeniu, ale na szczęście idea pozostaje nienaruszona. A z niej należy czerpać siłę do dalszego działania.

Pewnym paradoksem pozostaje, że Herling za najlepszego rewizjonistę grzechów mesjanizmu, do których unaocznienia w jego opinii niemało przyczyniły się Księgi..., uważa samego autora „broszurki”: „Mickiewicz samotny jest najlepszą odpowiedzią na wątpliwości, jakie budzić w nas może dzisiaj lektura Ksiag narodu i pielgrzymstwa polskiego" [s. 478]. Wieszcz na emigracji prowadził bardzo aktywną działalność społeczno-polityczną, o czym pokrótce przypomina przyszły diarysta. Jednak ,gdy sprawa Legionu [chodzi o utworzony w 1848 roku przez Mickiewicza Legion Polski - A. W.] spełznie na niczym, wycofa się Mickiewicz samotny i rozgoryczony z życia publiczne-

\footnotetext{
${ }^{43}$ Tamże, s. 279.

${ }^{44}$ G. Herling-Grudziński, W. Bolecki, Rozmowy w Dragonei, s. 114.
} 
go" [s. 479]. Tym samym domyka się pewien krąg Mickiewiczowskiej wędrówki, która została nakreślona piórem Herlinga. Tak jak wcześniej poeta, odrzucając w imię ojczyzny przyjaźń księżnej Zeneidy, świadomie decydował się na samotność pośród innych narodowości, tak teraz, wobec braku odzewu na swoją wieloletnią aktywność ze strony rodaków, i wśród nich wybiera (czy raczej zostaje zmuszony?) samotną egzystencję.

Jednak, mimo tylu gorzkich słów pod adresem wieszcza, to również on, Adam Mickiewicz, stanowi receptę na trawiące Polskę bolączki i w tym tkwi dostrzeżona przez Herlinga wielkość wieszcza. Jak informuje autor: „Przezwyciężony i odnowiony staje się dla nas Mickiewicz symbolem postawy emigracyjnej, której »samo słowo nie wystarcza«" [s. 480]. Przedstawiony wcześniej we wstępie biogram autora Dziadów po emigracji do Paryża to pełen pasji życiorys człowieka zmierzającego do konkretnego celu, który nawet po klęsce Legionów, chociaż pozostał w osamotnieniu, to szybko zapomina o porażce i zaczyna współtworzyć paryską „Trybunę Ludów” (czyli poddaje się ,przezwyciężeniu i odnowieniu”). Herling bowiem jest zwolennikiem głębokich przemian społecznych (czemu już dał wyraz w refleksji o dziele Krasińskiego) i ponadto uważa, że to właśnie „uspołecznienie narodu może jedynie wypełnić wyrwę, jaką romantyczny mesjanizm wytworzył pomiędzy narodem i jednostką" [s. 480]. I na tym polu pomoc znajduje u Mickiewicza, który chwilę po opublikowaniu Ksiag... dołącza do debaty prowadzonej przez emigrację na łamach „Pielgrzyma Polskiego”, aby w połowie lat 40. XIX wieku wziąć udział, „nie wyglądając biernie cudu w manifestacjach ludu paryskiego" [s. 479]. Autor wstępu mocno podkreśla, że Mickiewicz, który może być mylnie postrzegany przez pryzmat wskazanych jarzm mesjanizmu, sam też odczuwał potrzebę zmian społecznych (Herling ponownie da temu wyraz w 1949 roku podczas przemówienia z okazji 150 . rocznicy urodzin Mickiewicza ${ }^{45}$ ) i, co ważniejsze, jego sprzeciw nie był bierny. Tak więc Herling pokazuje, że mylne jest postrzeganie wieszcza jako poety zanurzonego wyłącznie w meandry mistycznego mesjanizmu w końcu Mickiewicz to człowiek, zgodnie z Herlingowską formułą, „przezwyciężony i odnowiony”, który nie waha się powiedzieć: „»Przyszedłem was zapytać, czy nie zbliża się czas, abyśmy stanowczo ruszyli z emigracji — nawet krokami ziemskimi. Moim jest instynktem abyśmy wyszli«" [s. 479]. Powołanie się na słowa jednego z wieszczów o należności podjęcia „ziemskich kroków” w tym kontekście jest niezwykle wymowne. Można powiedzieć, że Herling upomina się o szeroko rozumianą „filozofię czynu", która przecież zaistniała w epoce romantycznej.

Emigrant znajduje w Księgach... bardzo istotną dla siebie myśl, którą bez wątpienia akceptuje i nie poddaje jej większej reinterpretacji: „Na ich kartach wyrażona zostanie dobitnie konieczność rozmawiania z ludami Europy ponad głowami dworów i gabinetów" [s. 477]. Współgra to oczywiście $\mathrm{z}$ postulatem o rewolucji społecznej, a jednocześnie wzbogaca tę refleksję o sprzeciw wobec szeroko pojmowanego imperializmu: „Historiozoficzne przeciwstawienie ludów Europy »królom i gabinetom« obowiązuje nas po dzień dzisiejszy" [s. 481] — taki jest główny dezyderat wobec nowej emigracji i takie też treści dość łatwo odnaleźć na łamach samych Ksiag... ${ }^{46}$. Dlatego też cha-

${ }^{45}$ Por. G. Herling-Grudziński, „Z podniesiona jak zawsze głowa”, [w:] tegoż, Recenzje, szkice, rozprawy literackie. 1947-1956, zebrał Z. Kudelski, oprac. J. Bielska-Krawczyk i in., t. 2, Kraków 2010, s. 203-210.

${ }^{46}$ Warto jednak zaznaczyć, że Mickiewicz w swoim dziele wyznacza Polsce szczególną rolę w Europie - wystarczy przytoczyć takie sformułowania, jak np. „Zaprawdę powiadam Wam, iż cała Europa musi nauczyć się od Was, kogo nazywać mądrym" (A. Mickiewicz, Księgi narodu polskiego, s. 26), czy też: „Jesteście śród cudzoziemców jako Apostołowie śród bałwochwalców” (Tamże, s. 50). Nie będzie chyba zbytnią nadinterpretacją założenie, że Herling na te ustępy raczej 
rakterystyczne słowa Mickiewicza: „O wojnę powszechną za wolność ludów...”, zamykają wstęp Herlinga, a jednocześnie zostają określone jako „najpiękniejsze słowa Litanii pielgrzymskiej" [s. 477]. To ważna uwaga, ponieważ w Litanii, która kończy Księi..., jako argument za zmianami na mapie Europy kilkakrotnie wykorzystywana jest martyrologia Polaków (np. „Przez krew wszystkich żołnierzy poległych w wojnie za Wiarę i Wolność, / Wybaw nas Panie" ${ }^{\text {"47 }}$ ). Tonacja litanii ulega jednak zmianie właśnie po odczytaniu przytoczonych przez Herlinga słów. Jak zauważa Stefanowska: „Nie modli się [Mickiewicz - A. W.] przecież o cudowne wyzwolenie [...]. Nie prosi o »łaskę wolności«, prosi o warunki do walki o wolność, o prawo do czynu zbrojnego. [...] Toteż w perspektywie modlitw końcowych inaczej rysuje się cały utwór, ostrzej występuje związek z chwilą bieżącą i doraźny, agitacyjny cel broszury"48. Herling jawi się zatem jako uważny czytelnik, który dokładnie studiuje analizowane dzieło i ze szczególną troską wybiera z niego spostrzeżenia, które uznaje za najcenniejsze.

Tak więc łatwo zrozumieć, dlaczego Herling z taką pewnością stwierdza, że „Aktualność Ksiąg jest jednak nie tylko przerażająca, jest ona także, i to może nawet w nieporównanie większym stopniu — pouczająca" [s. 471]. Spostrzeżenia te, jako że otwierają rozważania eseisty, można oczywiście odnieść do całego dzieła, ale w pierwszej kolejności należy je wiązać z oczekiwaniem na „wojnę powszechną”. Dla Herlinga Księgi..., mimo wielu ,jarzm” je wypełniających, są ważną lekturą, o ile będzie się z niej czerpać tylko to, co jest ,wiecznie żywe i nieprzemijające”. Za taką wartość uchodzi oczywiście wezwanie Mickiewicza do walki o wolność ludów, walki związanej z rewolucją społeczną. Herling nawiązuje do tej myśli, jednak w pewnym momencie wydaje się, że emigrant przerywa dialog z Mickiewiczem, aby snuć już tylko własne refleksje. Ciekawie w tym kontekście brzmią słowa: „Naród poczuwający się do odpowiedzialności za losy państwa, świ ad omy swego krwawego trybut u [podkr. - A. W.], zahartowany w solidarności społecznej, wyleczony z mitów i przerostów elitaryzmu politycznego" [s. 480]. Autor mówi o odrzuceniu mitycznego podejścia, ale trudno nie odnieść wrażenia, że sam mitologizuje pewien odcinek rzeczywistości, a przynajmniej wpada w egzaltowany ton, który nie przystaje do dialogicznego charakteru całości. Niemniej, pokazuje to, że nawet tak wnikliwy obserwator, jak Herling, toczy trudną walkę z romantyzmem. Zwłaszcza że wcale nie neguje jego siły: „Żadne doraźne rozporządzenia i ustawy nie zatrą kolein, jakie wyżłobiło sobie w umysłowości polskiej przeszło stuletnie wychowanie romantyczne" [s. 480]. Postuluje, aby wynikający z propagowania postawy romantycznej „wyczerpujący się w jałowych problemach moralno-religijnych i psychiczno-narodowych dynamizm skierować w inne łożysko" [s. 480]. Mimo że mamy do czynienia, jak się z pozoru wydaje, ze wstępem do klasycznej lektury, jest to, jak zauważa Mencwel, „bardzo dobry zestaw założeń dla »długotrwałej pracy kulturalno-politycznej«, jasno też i celnie wysłowiony. [...] Jest to także jeden $\mathrm{z}$ ważniejszych tekstów programowych, jakie u nas napisano, i w antologii stu lat myśli polskiej odzyskałby swój blask" ${ }^{\text {,49 }}$.

się nie zgadza, gdyż owe uwagi Mickiewicza łatwo powiązać z jednym z jarzm, czyli megalomanią narodową.

${ }^{47}$ A. Mickiewicz, Księgi narodu polskiego, s. 61.

${ }^{48}$ Z. Stefanowska, Historia i profecja, s. 212-213.

${ }^{49}$ A. Mencwel, Przedwiośnie czy potop, s. 279-280. 
Powstanie kilku esejów Herlinga-Grudzińskiego w połowie lat 40. minionego wieku, w których były więzień sowieckiego obozu pracy podejmuje dyskusję z wybitnymi przedstawicielami XIX stulecia, wskazuje na silną potrzebę konfrontacji z myślą romantyczną w tak ważnym dla Polski czasie. Patronem rozważań Herlinga jest oczywiście Norwid, za którym współczesny emigrant podąża niemal bez zastrzeżeń. To od niego bowiem eseista uczy się, jak należy oceniać dziedzictwo romantyczne. Co więcej, list autora Vade-mecum do Józefa Ignacego Kraszewskiego, który Herling przypomina, traci prywatny charakter - grono odbiorców zostaje poszerzone; na wypowiedź Norwida powinna zwrócić również uwagę nowa polska emigracja. Krasiński z kolei został przedstawiony przez pryzmat swojego opus magnum. Chociaż Herling określa je jako „najbardziej interesującą powieść współczesną” [s. 407] z racji niezwykłych zbieżności z aktualnymi dla niego wydarzeniami, to najważniejszy staje się poczyniony przez Krasińskiego obraz „klas społecznych”. Autor szkicu ceni głębię opisu dwóch zwalczających się obozów, ale przy tym zaznacza, że lektura ta, jej symbolika, musi zostać przezwyciężona. Wreszcie — pierwszy z wieszczów. Dyskusja trudna, niekiedy bolesna, ale przecież niezbędna. Mimo że to właśnie Mickiewicza mógłby Herling oskarżyć o główny „współudział” w tworzeniu mitów epoki, to Księgom narodu polskiego i pielgrzymstwa polskiego zostaje przyznana, przynajmniej w pewnych aspektach, aktualność.

Wobec żywego wśród Polaków paradygmatu romantycznego pada, owszem, wiele gorzkich słów. Pisarz poddaje go głębokiej krytyce, zwalcza „cztery zasadnicze jarzma" romantyzmu, w dużej mierze sprzeciwia się mesjanizmowi. Nie można jednak powiedzieć, że Herling-Grudziński dokonuje bezrefleksyjnego ataku na romantyzm. Docenia w końcu wielkość epoki, chociaż na wytworzony przez nią „dynamizm” spogląda inaczej niż poprzednicy. Jednocześnie zdaje sobie sprawę, że epoka Mickiewicza wykształciła pewien wzór postępowania na obczyźnie, który należy ponownie przemyśleć w związku z nową sytuacją na politycznej mapie świata.

\section{LITERATURA}

Literatura podmiotu

Herling-Grudziński G., „Księgi narodu polskiego i pielgrzymstwa polskiego” na nowej emigracji, [w:] tegoż, Recenzje, szkice, rozprawy literackie. 1935-1946, zebrał. Z. Kudelski, oprac. W. Bolecki i in., t. 1, Kraków 2009, s. 471-481.

Herling-Grudziński G., List C.K. Norwida do emigracji polskiej, [w:] tegoż, Recenzje, szkice, rozprawy literackie. 1935-1946, zebrał. Z. Kudelski, oprac. W. Bolecki i in., t. 1, Kraków 2009, s. 485-487.

Herling-Grudziński G., Nad „Nie-Boska komedia”. Propozycja dyskusyjna, [w:] tegoż, Recenzje, szkice, rozprawy literackie. 1935-1946, zebrał. Z. Kudelski, oprac. W. Bolecki i in., t. 1, Kraków 2009, s. 407-412.

Literatura pomocnicza (literatura przedmiotu, rozmowy z autorem, inne pisma i dzieła literackie)

Bagłajewski A., „Żywi i umarli” - czytani po latach, [w:] Herling-Grudziński i krytycy. Antologia tekstów, wybór i oprac. Z. Kudelski, Lublin 1997, s. 397-403.

Bolecki W., Ciemny staw. Trzy szkice do portretu Gustawa Herlinga-Grudzińskiego, Warszawa 1991.

Breczko J., Poglądy historiozoficzne pisarzy z kręgu „Kultury” paryskiej. Przezwyciężenie katastrofizmu, odrzucenie mesjanizmu, Lublin 2010. 
Frankowiak A. M., Być wśród żywych i umarlych. Ewolucja twórczości eseistycznej Gustawa Herlinga-Grudzińskiego, Olsztyn 2003.

Giedroyc J., Autobiografia na cztery ręce, oprac. i posł. opatrzył K. Pomian, Warszawa 1994.

Herling-Grudziński G., Bolecki W., Rozmowy w Dragonei, Warszawa 1997.

Herling-Grudziński G., Dziennik pisany noca, t. 1 (1971-1981), Kraków 2011.

Herling-Grudziński G., Listy literackie, [w:] tegoż, Recenzje, szkice, rozprawy literackie. 19351946, zebrał. Z. Kudelski, oprac. W. Bolecki et al., t. 1, Kraków 2009, s. 315-318.

Herling-Grudziński G., Mickiewicz w Rzymie i w Moskwie. Ciekawe odkrycie literackie, [w:] tegoż, Recenzje, szkice, rozprawy literackie. 1935-1946, zebrał. Z. Kudelski, oprac. W. Bolecki i in., t. 1, Kraków 2009, s. 307-314.

Herling-Grudziński G., Mowa cieni, [w:] tegoż, Recenzje, szkice, rozprawy literackie. 19351946, zebrał. Z. Kudelski, oprac. W. Bolecki i in., t. 1, Kraków 2009, s. 289-291.

Herling-Grudziński G., Przezwyciężanie żeromszczyzny (O „Miliardach” Andrzeja Struga), [w:] tegoż, Recenzje, szkice, rozprawy literackie. 1935-1946, zebrał. Z. Kudelski, oprac. W. Bolecki i in., t. 1, Kraków 2009, s. 56-62.

Herling-Grudziński G., Wspomnienie o K. L. Konińskim, [w:] tegoż, Recenzje, szkice, rozprawy literackie. 1935-1946, zebrał. Z. Kudelski, oprac. W. Bolecki i in., t. 1, Kraków 2009, s. $488-497$.

Herling-Grudziński G., „Z podniesiona jak zawsze głowa”, [w:] tegoż, Recenzje, szkice, rozprawy literackie. 1947-1956, zebrał. Z. Kudelski, oprac. J. Bielska-Krawczyk i in., t. 2, Kraków 2010, s. 203-210.

Kleiner J., Zygmunt Krasiński. Studia, Warszawa 1998.

Kowalczykowa A., Poglady filozoficzne Zygmunta Krasińskiego, [w:] Polska myśl filozoficzna i społeczna, red. A. Walicki, t. I, Warszawa 1973, s. 306-347.

Krasiński Z., Nie-Boska Komedia, [w:] tegoż, Dzieła literackie, wybrał, notami i uwagami opatrzył P. Hertz, t. 1, Warszawa 1973, s. 323-417.

Krukowska H., hasło: Indywidualizm, [w:] Stownik literatury polskiej XIX wieku, pod red. J. Bachórza i A. Kowalczykowej, Wrocław 2009, s. 365-369.

Kudelski Z., Studia o Herlingu-Grudziński. Twórczość - recepcja - biografia, Lublin 1998.

Mencwel A., Przedwiośnie czy potop. Studium postaw polskich w XX wieku, Warszawa 1997.

Mickiewicz A., Księgi narodu polskiego i pielgrzymstwa polskiego, [w:] tegoż, Dzieła, t. 5, Proza artystyczna i pisma krytyczne, tom oprac. Z. Dokurno, Warszawa 1999, s. 9-62.

Olejnik T., O Polsce, Rosji, Europie $i$ wolności. Zygmunt Krasiński w świadomości drugiej emigracji, [w:] Zygmunt Krasiński. Nowe spojrzenia, pod red. G. Halkiewicz-Sojak i B. Burdzieja, Torun 2001, s. 521-536.

Pieróg S., Mesjanizm, [hasło w:] Stownik literatury polskiej XIX wieku, pod red. J. Bachórza i A. Kowalczykowej, Wrocław 2009, s. 536-540.

Pomian K., Herling-Grudziński - emigracja heroiczna, [w:] Herling-Grudziński i krytycy. Antologia tekstów, wybór i oprac. Z. Kudelski, Lublin 1997, s. 29-32.

Rzońca W., Norwid a romantyzm polski, Warszawa 2005.

Stefanowska Z., „Dziennik” Herlinga-Grudzińskiego, [w:] Herling-Grudziński i krytycy. Antologia tekstów, wybór i oprac. Z. Kudelski, Lublin 1997, s. 330-336.

Stefanowska Z., Historia i profecja. Studium o „Ksiegach narodu i pielgrzymstwa polskiego” Adama Mickiewicza, Warszawa 1962.

Święch J., Literatura polska w latach II wojny światowej, Warszawa 2010.

Waśko A., Prawda i parabola. O Gustawie Herlingu-Grudzińskim, [w:] Herling-Grudziński i krytycy. Antologia tekstów, wybór i oprac. Z. Kudelski, Lublin 1997, s. 94-109.

\section{HERLING-GRUDZIŃSKI IN DISCUSSION WITH NORWID， KRASIŃSKI，AND MICKIEWICZ}

The article consists of three parts, each focusing on a different essay of Herling's concerning the Romantic era. The author demonstrates how Herling reads Romantic works in order to search for valuable clues for $20^{\text {th }}$-century Polish immigrants. It appears that it is Cyprian Norwid and his 
sometimes critical view of the legacy of Romanticism that prove to be particularly appealing for Herling. The article also presents Herling's views on Zygmunt Krasiński's Nie-Boska Komedia [Non-Divine Comedy], in particular the Romantic representations of aristocracy and revolutionaries. It closes with an analysis of Ksiegi narodu polskiego i pielgrzymstwa polskiego [The Books and the Pilgrimage of the Polish Nation] by Adam Mickiewicz. Although Herling is skeptical of many of Mickiewicz's views, especially messianism, he can also see how his work still remains topical.

KEY WORDS: Gustaw Herling-Grudziński, Cyprian Norwid, Zygmunt Krasiński, Adam Mickiewicz, literary criticism in exile, reception of Romanticism, messianism

SŁOWA KLUCZOWE: Gustaw Herling-Grudziński, Cyprian Norwid, Zygmunt Krasiński, Adam Mickiewicz, publicystyka emigracyjna, recepcja romantyzmu, mesjanizm 